epiphany

Online Journal of the Faculty of Arts and Social Sciences

International University of Sarajevo

ISSN 1840-3719 / Volume 1 / No. 1

Fall 2008

\title{
From Coolie Hinterland to Babu Stardom: An Interview with Tabish Khair
}

\author{
Nilanshu Kumar Agarwal \\ Feroze Gandhi College
}

Born and educated mostly in Gaya, India, Tabish Khair is the author of various books, including the poetry collection, Where Parallel Lines Meet (Penguin, 2000), the critical study, Babu Fictions: Alienation in Indian English Novels (Oxford UP, 2001) and the novel, The Bus Stopped (Picador, 2004), which was short-listed for the Encore Award. His honours and prizes include the All India Poetry Prize (awarded by the Poetry Society and the British Council) and honorary fellowship (for creative writing) of the Baptist University of Hong Kong. Other Routes, an anthology of pre-modern travel texts by Africans and Asians, co-edited and introduced by Khair (with a foreword by Amitav Ghosh) was published by Signal Books and Indiana University Press in 2005 and 2006 respectively. Khair's latest novel, Filming: A Love Story, examines memory and guilt against the backdrop of the Partition and the 1940s Bombay film industry. Currently, he is Associate Professor, Department of English, University of Aarhus, Denmark. This perceptive literary figure discusses with Dr. Nilanshu Kumar Agarwal some tangling issues, concerned with Indian Writing in English.

NKA: Indian English fiction is pervaded by the element of alienation in it. A whole breed of the contemporary novelists talks about the disturbed psychological condition of the individual on account of the enormous alienation. Are these novelists suitable enough to display this mental state of the man? Most of them are from the upper strata of life. Anita Desai was born to a German mother. Salman Rushdie was born of an affluent Muslim family in Bombay. He was educated, first at Cathdral School in Bombay, a classic neo-colonial enclave that 'groomed' him, he says, for the exclusive British public school, Rugby, and England, where he was headed next. John Mee in his essay 'After Midnight: The Novel in the 1980s and 1990s' has talked of a group of writers identified 
with Delhi's elite St. Stephen's College. Allan Sealey, Amitav Ghosh, Shashi Tharoor, Upmanyu Chatterjee, Rukun Advani, Mukul Kesavan and Anurag Mathur were all students of this college in the early 1970s. Kiran Desai, the daughter of Anita Desai, was born in New Delhi, India, and lived there until she was 14. She and her mother then lived in England for a year, and finally moved to the United States where she studied creative writing at Bennington College, Hollins University and Columbia University.

How can these people from the upper classes of society feel the pains of the people from the lower sections of the society? Is it not a sort of intellectual dishonesty to write about an experience, which they have never felt, being members from another group of the society? To use your expression, how can the Babus \{middle or upper class, mostly urban (at times cosmopolitan), Brahminized and/or westernized and fluent in English\} internalize the psychology of the coolies \{non-English speaking, not or not significantly westernized, not or less Brahminized, economically deprived, culturally marginalized and, often rural or migrant-urban populations\}?

TK: Any representation, or claim to represent, is problematic. Can I represent anyone other than myself? On what grounds can I speak for someone else? When I speak for someone else, don't I actually put my words in his/her mouth? Actually, it is worse than that: can I even speak for myself? Is my self-understanding so profound that I can claim to understand myself thoroughly, to see myself as transparent enough to be represented fully in my own words? (And yet representation is both an existential and political necessity: we need to represent ourselves, society is run by our 'representatives' etc.) So, of course, when a privileged class starts writing about a less privileged class, the matter gets even more complicated and dubious. But this is not to dismiss Indian English fiction per se. I do not think many Indian English writers set out to represent anyone: they basically tell stories as they see them. It is largely in the West that they are considered to be 'representative.' Some of them let this impression stay unchallenged, as it provides them with 'authenticity' and a larger readership in the West. Moreover, any fiction is about things that one has not experienced. That is why it is fiction and not a factual essay, not journalism or a report or an autobiography. Fiction does not really make truth claims, at least by definition. So, one cannot really dismiss Indian English creativity on those grounds. My book BABU FICTIONS argued for an awareness of this problem (which is largely ignored); it did not castigate or dismiss 
Indian English fiction in general. One can wish (as I do) that Indian English writers would address this problem more directly in their fiction - and some, like Amitav Ghosh, tend to do so. I think that an awareness of the problem will make Indian English fiction more complex, varied and vibrant: as it is, much of Indian English fiction today is becoming a kind of polished story-telling, with very little cutting edge in terms of form, politics, structure, genre etc.

NKA: What is the target audience of this Babu fiction? Sir, the standard of English education India is very low. People can not even easily comprehend English newspapers and magazines. So, how will they follow the creative works of Indian writers in English language? Does it not mean that this Babu literature is also just for the Babu audience? Is it just for the elite classes and far removed from tastes of the masses? What do you say?

TK: I think many creative writers probably write for themselves: they choose to write in the language they are most comfortable with. Some writers might have a readership in mind too, and you are right that there is a very limited readership in India: very few Indians are fluent in English and even the educated middle class hardly reads fiction in English. So, by default, the readership of Indian English fiction is 'global': not just 'Western', for there is a large Indian (even Asian) diaspora that seems to be reading these novels in greater numbers and there are 'globalised' Indians in the bigger cities of India, Pakistan etc. You know, the term Babu has a double edge: it is used as a term of respect by poor Indians and it was also often used by the British as a term to scoff at Anglophone, middle class Indians. 'Babu' fictions seem to have a similar position: for better and worse, they fall between two stools, whether seen in geographical, cultural or class terms. But then written 'serious' literature, in any language, is at least partly removed from the tastes of the 'masses.' In the case of Indian English fiction the gap is just much wider at times.

NKA: How is this literature received in the West? Do the scholars in the West support it? Or is it rejected by the Westerners as a sheer attempt by the subjects of the former colonies to be equal with the master? Is it taken seriously there or considered merely an 
imitative subway of the western literature? Please respond, sharing your own experiences as a novelist and critic.

TK: This is a difficult question to answer, as the 'West' is just as varied as India, and reactions tend to vary. There is some interest, but not as much as people assume in India. The (limited) interest that exists might be for different reasons: genuine interest in other cultures and literatures, raj nostalgia, cultural exoticism, publishing fads, reaction to some political event etc. Again, the response of the 'West' differs from place to place and genre to genre. For instance, you can see that Indian English novels have been accepted far more widely than Indian English poetry. One can argue that Indian English novels that make structural and critical experiments are less likely to be accepted and promoted than Indian English or postcolonial novels that are seen as the work of great smooth 'story-tellers'; or, a 'magical realist' novel will be accepted more widely than a 'modernist-type' novel. There are long historical reasons for these slants, most of them rooted in the ways in which many Europeans and people of European descent see themselves and other (African, Asian etc) cultures. By and large, I think that the earlier interest in postcolonial works - which included some really different narratives by writers like Achebe, Raja Rao etc - has been replaced by a tendency to focus on the multi-cultural west, and hence, say, novels by Monica Ali, Hanif Kureishi or Zadie Smith. I think the 'Western' gaze has become more self-centred in recent years, though the Western 'self' has been largely accepted as multicultural. So, perhaps, we should start seeing writers like Rushdie, Hari Kunzru or Zadie Smith, largely bred in the 'new', post-war, self-consciously 'multi-cultural' West, as basically writing about the 'new' 'multicultural' West for the West, even when they write about India. There is nothing wrong with that: these are writers who grew up in the West. Why should they have the same critical or artistic or political agenda as writers who grow up in India or Nigeria? I think the fault is again how they are seen by others, including by us in India: we need not make such a smug fuss when a Rushdie or a Naipaul gets a major award. But I guess we in India are also at times starved of Western attention and clutch at whatever straw comes floating by, even if that straw is largely from the loft of another land! 
NKA: How will you distinguish between the Indian English novels before and after 1981 (the year when Midnight's Children was out.)? Do you find this Babu element to be more prominent in the Post 1981 scenario?

TK: Not totally, perhaps, but there often is a difference of type. Most of the major pre1981 Indian English writers grew up in India: R. K. Narayan, Raja Rao, Nirad C. Chaudhuri, Manohar Malgonkar, Khushwant Singh, Kamala Markandaya, Shashi Deshpande etc. They might have gone abroad to settle or study later on, but they spent most or all of their formative years in India. The situation is different now: many (but not all) the big 'Indian/Pakistani' names today have grown up outside India, mostly: Rushdie, Naipaul, Kunzru, Kureishi etc etc. Surely, they cannot be expected to write similar literature.

NKA: How far is it possible for the creative/ critical writers from the coolie sections of the society in India and elsewhere to get their works promoted? Can a coolie writer easily find a publisher? Do the big publishing houses come forward easily to publish these authors? The strong network of the Babus does not allow the coolies to get their works published. What do you think about all this? Please make a realistic comment.

TK: I can see your point, and perhaps more so because I grew up and was educated in the 'coolie' hinterlands! It is true, if you write in English, you need to get into the big cities of India or abroad, or have very close connections with them. It is not just a question of Babu dominance; one's exposure to both English and world literature is seriously limited in 'coolie' contexts. Indians do not speak English like people do in Jamaica or parts of Nigeria: in these places, it is also partly a street language and hence a writer can come up from the streets and use that language to make space for his writings. It would be accepted if the writer, like Ken Saro-Wiwa or Sam Selvon, was extremely talented. But I do not think that a similar situation exists in 'coolie' India, which does not speak English or speaks English only on occasions and in a very halting manner. There is no real street culture in English to enable a writer like that to come up in India (Manipur and some small areas of places like Mumbai are partial exceptions to this). So, it seems to be an uphill journey for a 'Coolie' to break into the world of 'Indian English' (let alone Global English) publishing. But then, why should a 'Coolie' Indian write in English if s/he can write better in other Indian languages?! Due to 
personal reasons, I grew up reading and writing much more English than Hindi or Urdu, though I know Hindi and Urdu too. If that had not been the case, I would have preferred to write in Hindi or Urdu. I still hope to write at least one novel in one of those languages.

\section{Notes}

The information about the authors in the first question is borrowed from the following sources:

- Mehrotra, Arvind Krishna, ed. An Illustrated History of Indian Literature in English. Delhi: Permanent Black, 2003.

* Walsh, William. Indian Literature in English. London: Longman, 1990.

* <http://en.wikipedia.org/wiki/Kiran_Desai>.

The interviewer Dr. Nilanshu Kumar Agarwal is Senior Lecturer in English at Feroze Gandhi College, Rae Bareli, (U.P.), India. He has his doctorate on T.S. Eliot from Allahabad University. His interviews with a number of contemporary literary figures, as well as his research papers, book reviews, articles and poems have appeared in publications, including The Vedic Path, Quest, The Confluence, Kafla Intercontinental, Pegasus, IJOWLAC, The Journal, Promise, The Raven Chronicles, Yellow Bat Review, Poetcrit, Carved in Sand, Turning the Tide, Blue Collar Review, Bridge-in-Making, Katha kshetre, Hyphen and South Asian Review. Several anthologies have selected his poems and articles. His poem "To Lord Krishna" is in the celebrated anthology, The Pagan's Muse, Citadel Press. Several of his literary pieces have been included in The People's Poet: Summer Community Magazine of 2004. He has also edited a critical book on Stephen Gill, which is to be published shortly. 